
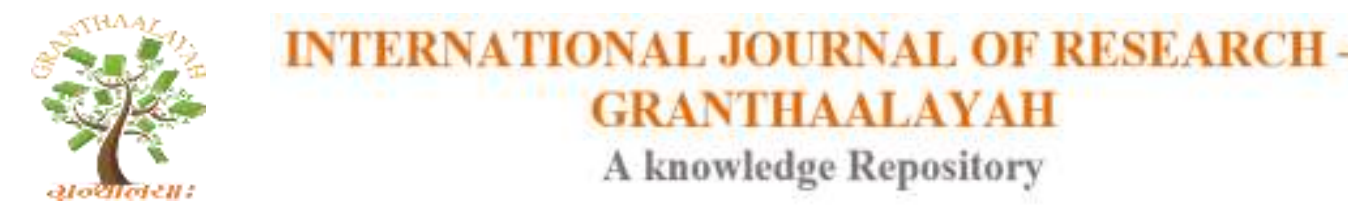

Science

\title{
SOLAR ENERGY: A POTENTIAL SOURCE OF RENEWABLE AND CLEAN ENERGY
}

\author{
Deepak Aryal *1 \\ ${ }^{* 1}$ Central Department of Hydrology and Meteorology, Tribhuvan University Kirtipur-10, \\ Kathmandu, Nepal
}

\begin{abstract}
This paper reports analytical review results on the global and national importance of solar energy as a clean and renewable source of energy. Pre-monsoon and post monsoon seasons have higher mean monthly sunshine duration (about 8 hours/day) than summer (about 5 hours/day) and winter (about 7 hours/day) seasons in Kathmandu. The lowest sunshine duration during summer season is attributed to the effect of monsoonal clouds during that period. Pre-monsoon and monsoon seasons receive solar energy of about $250 \mathrm{~W} / \mathrm{m} 2$ and $200 \mathrm{~W} / \mathrm{m} 2$ respectively. The winter season receives the least amount of solar radiation (about $150 \mathrm{~W} / \mathrm{m} 2$ ). Results show high prospect of solar energy utilization both in rural and urban areas of Nepal.
\end{abstract}

Keywords: Solar Energy; Renewable and Clean Energy; Sunshine Duration; Air Pollution.

Cite This Article: Deepak Aryal. (2018). "SOLAR ENERGY: A POTENTIAL SOURCE OF RENEWABLE AND CLEAN ENERGY." International Journal of Research - Granthaalayah, 6(8), 214-217. https://doi.org/10.29121/granthaalayah.v6.i8.2018.1452.

\section{Introduction}

People started using energy in their daily lives since the beginning of civilization. First they burned wood and obtained sufficiently high temperature for cooking and heating, as well as melting metals, extracting chemicals and converting mechanical power. During burning, the carbon in wood combines with oxygen $\left(\mathrm{O}_{2}\right)$ to form carbon dioxide $\left(\mathrm{CO}_{2}\right)$, which then absorbed by plants and converted back to carbon for use as fuel again. Since industrial revolution (i.e. at the end of $18^{\text {th }}$ century), all fuel demand was not sufficient by wood, and then people began to use fossil fuels, e.g. oil, coal and gas. With the increase in world population there is an ever-increasing demand of energy. Now the world is suffering from many kinds of energy and environmental problems. Energy is indispensable for human beings. Because of the rapid increase of global population and the advent of modern era, energy consumption rate is increasing and human beings are becoming more dependent on energy. Consequently, traditional fossil fuels, such as coal, oil, natural gas, which are limited and their reserves will run out in the near future (Neville, 1995). Also, people are well aware of the dark side of the use of fossil fuels that has contributed to local or regional air pollution and unpredictable, probably irreversible climate changes through $\mathrm{CO}_{2}$ emission in many 
parts of the world. The negative consequences, such as acid precipitation, stratospheric ozone depletion, hurricane severity and the greenhouse effect (Climate change) are occurring in the world. In addition to these environmental problems, the by-products of burning fossil fuels, such as nitrogen oxides are harmful to our health.

So, there is an increasing need for cheap and clean energy sources for the present and the future as well. Solar energy is the most attractive and reliable source of alternative energy because it is clean and renewable (Markvart T., 2000). In other words, the use of sunlight offers a conceivable alternative to worldwide energy related problems. The purpose of this paper is to analyze and report prospect of solar energy in Nepal. In order to draw conclusions solar radiation data have been analyzed and research results published by previous researchers such as related to world's power demand and solar energy potential in Kathmandu have been referenced.

\section{Data and Method}

Data and available necessary information for the study were collected from various sources. Solar radiation and sunshine hour data from different meteorological stations were collected from the Department of Hydrology and Meteorology (DHM), Government of Nepal and Water and Energy Commission Secretariat (WECS, 2006) (WECS Homepage). The time series data were analyzed in this study. Also, information and data were collected from different official annual reports, bulletins, books, journals and various dissertations available in the Central Department of Hydrology and Meteorology, Tribhuvan University.

\section{Results and Discussion}

\section{World Power Demand Versus Probable Power Available}

Figure 1 shows world power demand and total power available over the next century based on the estimation by U.S. Department of Energy (https://science.energy.gov/fes/). It is assumed that both total power available and power demand will increase with same ratio until 2010 year, however, after that, demand will increase significantly in comparison to total power available. As fossil fuels like oil, coal, natural gas start to decline irreversibly, which indicates that the world will be facing energy crises after a decade. In order to meet the power demand scientists are doing researches on the possibility of safe, reasonable and environment friendly energy sources.

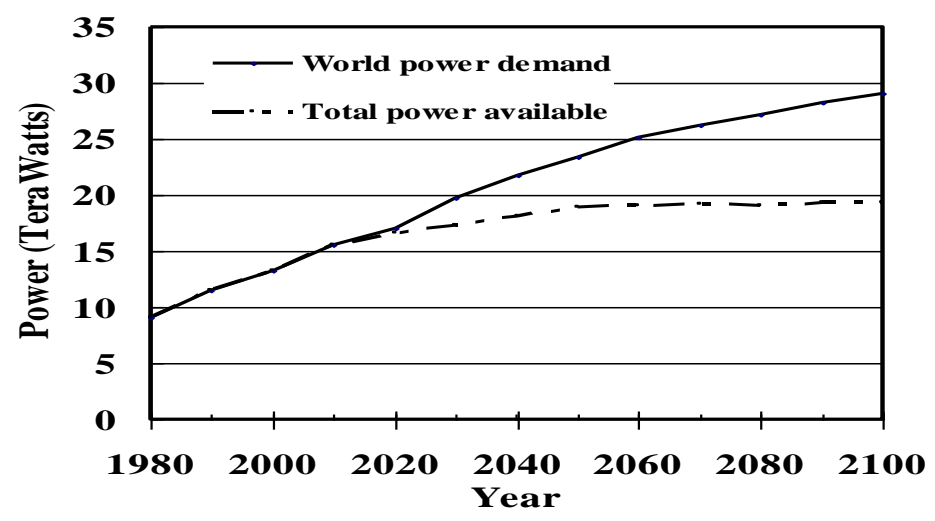

Figure 1: World power demand versus total probable power available 


\section{Utilization of Solar Energy and Prospect of Utilizing It in Nepal}

Nepal receives ample amount of solar energy due to its favorable location and topography. The average solar radiation varies from $3.6-6.2 \mathrm{kWh} / \mathrm{m}^{2} /$ day, and the sun shines for about 300 days a year (WECS report, 2006). The utilization of solar energy is favorable in many parts of the country, particularly in the mountainous areas where intensity of solar radiation is quite high. According Regmi (2010) the current status of solar home system installed in Nepal from 1992 to 2005 indicates increasing trend of solar home systems installation in Nepal (Schweizer-Ries and Preiser, 1997). The use of solar photovoltaic is increasing rapidly in the country since the year 2000 after the provision of subsidy by the Government of Nepal. This is a quite favorable trend towards environmental friendly environment.

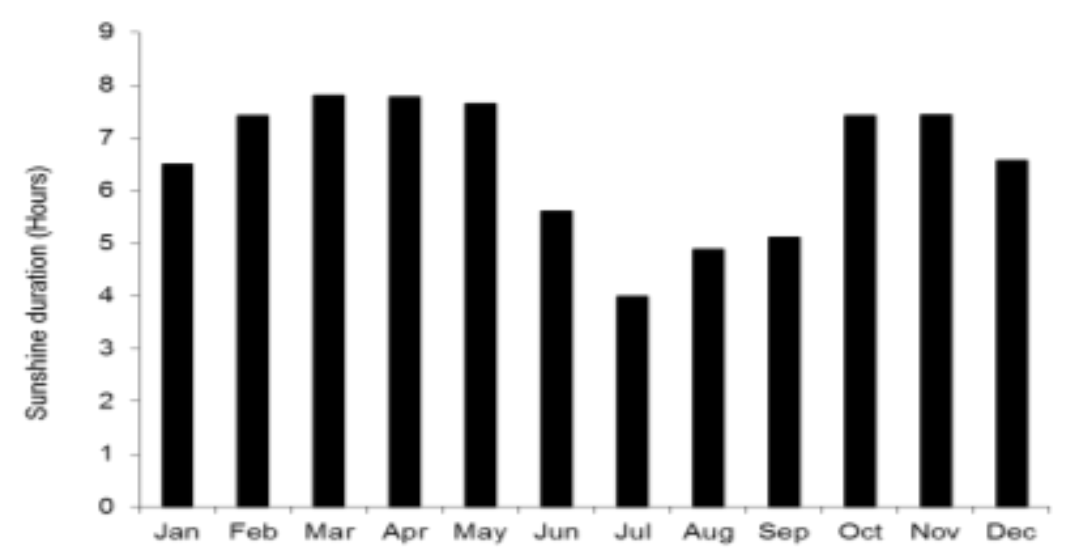

Figure 2: Sunshine hours of Kathmandu.

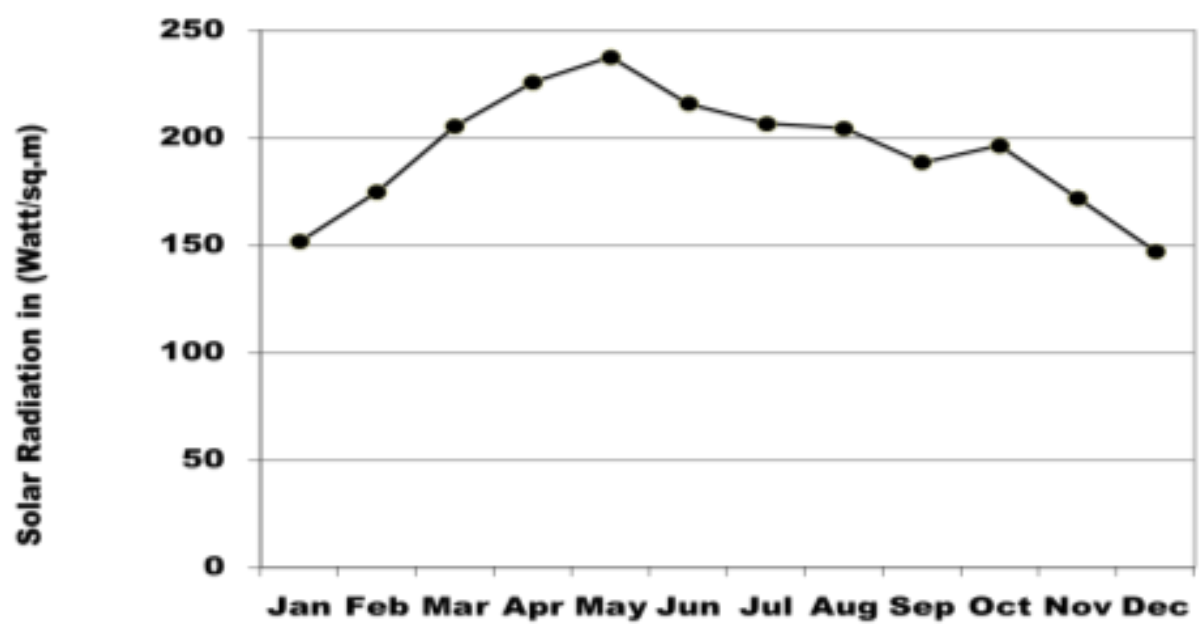

Figure 3: Mean monthly solar radiation of Kathmandu.

Figure 2 shows the mean monthly sunshine duration in Kathmandu valley. It is clear that premonsoon and post monsoon seasons have higher sunshine duration (about 8 hours/day) than summer (about 5 hours/day) and winter (about 7 hours/day) seasons. The lowest sunshine duration during summer season is attributed to the effect of monsoonal clouds during that period. 
Figure 3 shows mean monthly solar radiation intensity in Kathmandu valley. Pre-monsoon and monsoon seasons receive solar energy of about $250 \mathrm{~W} / \mathrm{m}^{2}$ and $200 \mathrm{~W} / \mathrm{m}^{2}$ respectively. The winter season receives the least amount of solar radiation (about $150 \mathrm{~W} / \mathrm{m}^{2}$ ).

According to 2001 census (CBS Homepage: www.cbs.gov.np/), a total population of Kathmandu valley only was about 701,962. However, present (2017) population of the valley is 25,10,788. The Total population of Nepal is $29,624,035$. The valley is especially vulnerable to air pollution due to an exploding population inflow, rapid urbanization, valley centric industrialization and significant increase of vehicles. Thus, solar energy / electricity could be the best option for energy and environmental problems in Nepal.

\section{Concluding Remarks}

Review results confirmed that the prospect of using solar energy is very encouraging in Nepal.

Nepal's rural settlements are quite scattered. Installation of solar home systems in such scattered settlements is beneficial and economical. For crowded urban settlements utilization of solar energy is useful to reduce environmental pollution problems as well as to solve energy shortage problems.

\section{References}

[1] Central Bureau of Statistics, Nepal (CBS) Homepage: www.cbs.gov.np/

[2] Markvart, T. (2000), Solar Electricity, $2^{\text {nd }}$ edition, University of Southampton, UK, Chapter 1, pp. 1.

[3] Neville, R.C. (1995). Solar energy conversion the solar cell, $2^{\text {nd }}$ ed., Elsevier Science B.V., Amsterdam, Netherlands.

[4] Regmi, S. (2010), Renewable Energy Potential and Environmental Issues in Nepal, M.Sc. Dissertation, Central Department of Hydrology and Meteorology, T.U.

[5] Schweizer-Ries, P. and Preiser, K., "Socio-Technical analysis of solar home systems in the Nepalese Himalaya". 14 ${ }^{\text {th }}$ European Photovoltaic Solar Energy Conference, Barcelona, Spain, 2552-2555 (1997).

[6] U.S. Department of Energy (https://science.energy.gov/fes/).

[7] WECS (2006). Energy Synopsis Report (no. 7, Seq. no. 489), Kathmandu, Nepal.

*Corresponding author.

E-mail address: deepak@ cdhmtu.edu.np/daryal1@ hotmail.com 